\title{
Modeling biomass flows at the farm level: a discussion support tool for farmers
}

\author{
Nadine ANDRIEU ${ }^{1,2 *}$, Daniel Maia NoGUEIRA ${ }^{3}$ \\ ${ }^{1}$ CIRAD, UMR Innovation, 34398 Montpellier, France \\ ${ }^{2}$ CIRDES, Bobo Dioulasso, Burkina Faso \\ ${ }^{3}$ Embrapa Semi-Árido, BR 428, km 152, Zona Rural, Cx. Postal 23, CEP 56300-970, Petrolina-PE, Brazil
}

(Accepted 3 October 2009)

\begin{abstract}
Many simulation models that are used to assess the impact of mixed farming systems have a high level of complexity that is not suitable for teaching farmers about the impacts of their practices. In this paper, we present a model that was developed and used with farmers as a discussion support tool to address the impacts of farming management strategies on farm resources. We assumed that the characterization of biomass flows at the farm level would provide a simple framework for designing a discussion support tool for farmers. The study was carried out in the semi-arid region of Brazil, where areas of native vegetation of the Caatinga Biome have been reduced in recent decades due to population pressure. In this region, simulation models are not used to discuss the impact of practices. We decided that a model for this purpose should: (1) be simple enough to be used by farmers, (2) be consistent with existing data, and (3) take into account the three main biomass management strategies. The model we built simulates biomass exports (harvest, animal intake, clearing vegetation of Caatinga), imports (purchase of fodder), and returns (animal manure) for farms with different vegetation types (Cenchrus ciliaris, Sorghum bicolour, Opuntia sp. and Caatinga native vegetation). We used the model to compare three management strategies over a 15-year period and found that the strategy that allows for the preservation of Caating a vegetation is less sensitive to bad years but results in a reduced herd size. We validated the use of this model by testing it with farmers. We found that farmers were interested in using the model as a learning (38\%), management (33\%), or prospective tool (24\%). This study shows that the dynamic modeling of biomass flows provides a simple and operational framework to analyze the impact of farming systems on farm resources with farmers. Contrary to current dynamic biophysical models that are based on extensive experimental data, this model does not give accurate predictions but allows both farmers and researchers to learn the impacts of farming systems. The complexity of the model should be increased progressively as farmers improve their understanding of the underlying processes.
\end{abstract}

mixed crop-livestock farming systems / simulation model / Caatinga / sustainable development

\section{INTRODUCTION}

Today, modeling and simulation approaches are increasingly used to assess the sustainability of farmers' production strategies (Tamubula and Sinden, 2000; Sadok et al., 2008), and the long-term impacts in particular. But models that are designed for the long-term analysis of farming strategies and intended to be used to teach farmers should be operational models (Bockstaller et al., 2008), in which the choice of input variables is based on the availability of data.

For mixed farming systems, the analysis of biomass flow implemented by farmers during one cropping season provides an efficient framework for understanding how the system operates. Indeed, it enables us to study the relationships between the cropping and livestock components of these systems and

*Corresponding author: nadine.andrieu@ cirad.fr represents a systemic approach to biophysical and decisional processes (Haberl et al., 2004). Some authors have used these flow-oriented approaches to diagnose the impacts of farming systems on farm resources, but they mainly focused on the impact of biomass flows on nutrient resources (De Jager et al., 2001; Haileslassie et al., 2007) or made a static diagnosis with no estimation of the long-term change in the systems (Briggs and Twomlow, 2002). With simple models, we believe that modeling of biomass flows could be an appropriate tool to evaluate the impact of farming systems on farm resources with farmers.

In the semi-arid area of Brazil, because of the low and irregular spatio-temporal distribution of rainfall and the low investment capacity, smallholder farming systems use a low amount of agricultural input. In addition, land distribution has led to a decrease in the size of the farms, and consequently to an increased pressure on natural resources through loss of fertility 
and biodiversity. The native vegetation of the Caatinga Biome is being overgrazed by extensive cattle raising or replaced by cultivated crops and has lost $50 \%$ of its vegetation cover and biodiversity (Figueirôa et al., 2006). For fodder purposes, Cenchrus ciliaris is cultivated as the main diet of the livestock.

The deactivation of the official extension service and the low level of technical training of farmers are further contributing to the perpetuation of non-sustainable practices.

The challenge for researchers is to develop discussion support tools that address the impacts of the current farming practices on the environment to promote the sustainable farming of Caatinga areas.

The aim of this article is to present a discussion support tool that is based on modeling of biomass flows that occur in the farming systems during the dry season.

We first present the methodological choices that were made to build the model. We then present and discuss the model, how we used it to diagnose the impacts of current farming systems, and the opinions of farmers who participated in its validation.

\section{MATERIALS AND METHODS}

\subsection{Description of the study zone and overall framework}

Caatinga is the largest biome of the semi-arid region of Brazil. Caatinga covers approximately $800000 \mathrm{~km}^{2}$ (Figueirôa et al., 2006). The vegetation is deciduous; trees lose their leaves during the dry season.

The study was carried out from 2005 to 2006 in the district of Acauã (latitude: $8^{\circ} 12^{\prime} 54^{\prime \prime}$, longitude: $41^{\circ} 4^{\prime} 55^{\prime \prime} \mathrm{W}$ ) in the semi-arid area. The yearly rainfall is $560 \mathrm{~mm}$. Rains fall during a single wet season, consisting of short intense storms over a 5 -month period between November and March. This is the period of production of biomass by food crops, fodder crops and vegetation in Caatinga. The dry season is between April and November and is the period of consumption of fodder stocks for the herds.

This district is characterized by one of the lowest indices of human development in the country, with a low level of infrastructure and services. Many farms produce only for subsistence. The average size of a farm is 70 ha, but there is a trend to decrease the total area. Traditional management of vegetation in Caatinga for mixed farming-systems was based on extensive grazing of vegetation of Caating $a$ by livestock. The clearing and burning of this vegetation allowed for temporary cropping of fields with short-cycle crops (bean, maize, and cash crops, such as cotton) and the use of wood for charcoal production. A fallow period of more than 10 years allowed for the reconstitution of vegetation and fertility. The introduction of artificial pastures, such as the buffel grass Cenchrus ciliaris, in the eighties contributed to the continuous cultivation of cleared areas (Andrieu et al., 2007). The introduction of these pastures was a means of land appropriation and of intensification of farming systems. The extension of Cenchrus reflected an increased interest in farming for stock breeding because of the higher sensitivity of cropping to drought.

Our analysis framework was based on the description and quantification of the areas of production and the concentration of plant biomass on the farm, such as cultivated or native vegetation areas, and the biomass flows between the areas (Tonneau et al., 2002). The characterized flows corresponded to a combination of exports by harvests or animal intake, imports by purchase of fodder, transfer/return of biomass by tillage operations, use of manure, and moving animals around. The dynamics of the systems were then simulated to diagnose their sustainability, and particularly their long-term impact on Caatinga areas.

Fourteen farmers with a range of production structures were selected for the design phase of the model. For each of the fourteen farms, the biomass flows were characterized by observations made on the field scale as well as by interviews at the beginning, middle and end of the dry season. A static biomass flow model was created for each farm and verified with the farmer. Common models between farmers translated to common management strategies. A generic conceptual model accounting for the main identified strategies was then developed by a team of researchers and implemented.

We selected 21 other farmers involved in a project for training sustainable development agents (Menezes et al., 2007) to participate to the subjective validation of the model (Coquillard and Hill, 1997).

\subsection{Development of the model}

In the construction of the model it was necessary to choose the study scale, time step and level of detail (Coquillard and Hill, 1997). We decided that the model should: (1) take into account the strategies implemented by the farmers, (2) be simple so it can be used as a training tool, and (3) be consistent with existing data.

\subsubsection{Accounting for the strategies implemented by farmers}

Three main strategies were identified for the management of biomass: (Strategy 1) an extensive strategy, which includes several different areas (buffel grass (Cenchrus ciliaris), paddle cactus (Opuntia sp.), Caatinga native vegetation, sorghum (Sorghum bicolor (L.)) and elephant grass (Pennisetum purpureum)); (Strategy 2) semi-intensive strategies, which are less diversified; buffel grass is the main fodder resource for the herd, and protein-rich feed supplements can be purchased mainly for dairy production; (Strategy 3) intensive strategies, which use buffel grass as the only fodder resource.

In contrast to some other semi-arid regions of Brazil and Africa, the three management strategies identified are carried out in relatively closed farming systems because (1) farmers buy few inputs, (2) the production is mainly dedicated to family subsistence and animal feeding during the dry season, and (3) there are no more common grazing areas. 
To account for these three strategies, the model should first be able to simulate the needs of the herd during the dry season. The model must then simulate, as a function of rainfall, the production of biomass in the different areas that will be used for grazing during the dry season or as fodder stocks. We chose the areas to be simulated based on their function in the production system. Buffel grass often represents the basic feed of the herd during the dry season. Sorghum or elephant grass are used to produce fodder stocks. Paddle cactus is collected mainly in the event of a very dry year. Caatinga areas are another kind of reserve area that enable the farmer to increase the area of buffel grass after its clearing; litter and shrubs in this area can also be grazed during the dry season in case of insufficient fodder stocks. The model should also be able to simulate the decisions the farmer makes to manage the different fluxes: the clearing of the Caatinga native vegetation, the use of the different feed resources during the dry season, and the sale of animals as a source of cash. Specific management strategies could be accounted for by modifying the number of areas, the animal carrying capacity, and the threshold values for decisions.

\subsubsection{Simple and consistent with the existing literature and field data}

The level of detail that should be included in a model depends on the objective of the modeling process and on the available data (Coquillard and Hill, 1997). Our study was executed in a data-scarce environment. Our modeling endeavor highlighted several gaps in the available data on the quantification of nutrient cycles and the effects of weather in the study zone and the lack of biophysical models suitable for adaptation.

We also needed to choose a level of detail that would allow us to develop simple models to facilitate interactions with the farmers. We hoped to achieve simplicity not only in the outputs but also in the content of the model. Moreover, when the number of variables is too high, the model loses its predictive capacity (Hakanson, 1995). Thus, a yearly time step was chosen to avoid creating a data-rich model based on a daily time step. The simulated year was divided into two seasons: the rainy season, which is the period of biomass production, and the dry season, which is the period of consumption of fodder stocks.

We decided to focus on the phosphorus cycle because of the limiting character of this element in the study zone: $89 \%$ of the semi-arid zone of Brazil displays a phosphorus deficit (Sampaio et al., 1994). Only partial phosphorus balances were simulated to represent the flows that are visible to farmers, such as exports by harvests and returns by animal feces. Phosphorus losses due to leaching and erosion were not included in the present analysis because the cost of quantifying such processes is not reasonable in the context of farmers' learning and action (Defoer et al., 1998).

\subsubsection{Implementation}

To implement the model, we chose an object-oriented approach that has been shown to be the most efficient for handling complex systems (Keating and McCown, 2001). This approach contributed to the modularity of the model and enabled: (1) new factors to be added without major changes in the existing code; (2) greater flexibility in the maintenance and the updating of the simulators; and (3) the life and the utility of the model to be prolonged.

In object-oriented approaches, the objects are generally inspired by components of the real system: the fields, farmer, herd, stocks of grain and fodder, and weather. The main attributes and functionalities of each kind of object are described by an entity called the "class". For example, a "field" class describes the main attributes of all the "field" objects. Each object in the same class, such as each "field" object, is made specific by the values of its attributes.

The first step was to design a conceptual model using unified modeling language (UML) to (1) represent the different components of the model and their links, and (2) allow local researchers to validate an early representation of the model.

Then, the conceptual model was implemented using Python. This is an interpreted language that is interactive, can run on different operating systems, and has an interpreter that can be downloaded for free at www.python.org. Lastly, a sensitivity analysis was carried out to test the impact of different parameter values on the outputs.

\subsubsection{Validation}

Subjective validation consisted of asking experts, in this case the 21 farmers, if the behavior of the model agreed with their knowledge of the real system. Cros et al. (2001) determined that subjective validation was the only possible process for complex systems. Here, subjective validation had two purposes: (1) to determine whether or not the outputs of the model were accurate, and (2) to evaluate whether or not the model could be useful for the farmers' learning process.

The validation was carried out with farmers that were involved in a project for training sustainable development agents during a work session of two half days.

The first step of the validation was a presentation of the overall objective, the processes that were simulated, the simplifications, and the inputs that were used by the model. The second step was a presentation of the decisional model, with the description of the rules that were simulated. The third step was the analysis of a table that showed an example of outputs simulated for a virtual farm, the kind of diagnosis that could be done based on the analysis of these outputs, and the outputs obtained with an alternative management strategy. The fourth step was the running of the model with case studies using three participants. The last step was an anonymous evaluation by the farmers using a questionnaire made up of two parts: (1) an evaluation of the decision rules and the main outputs, their understanding of the model, the aspects that they misunderstood, 


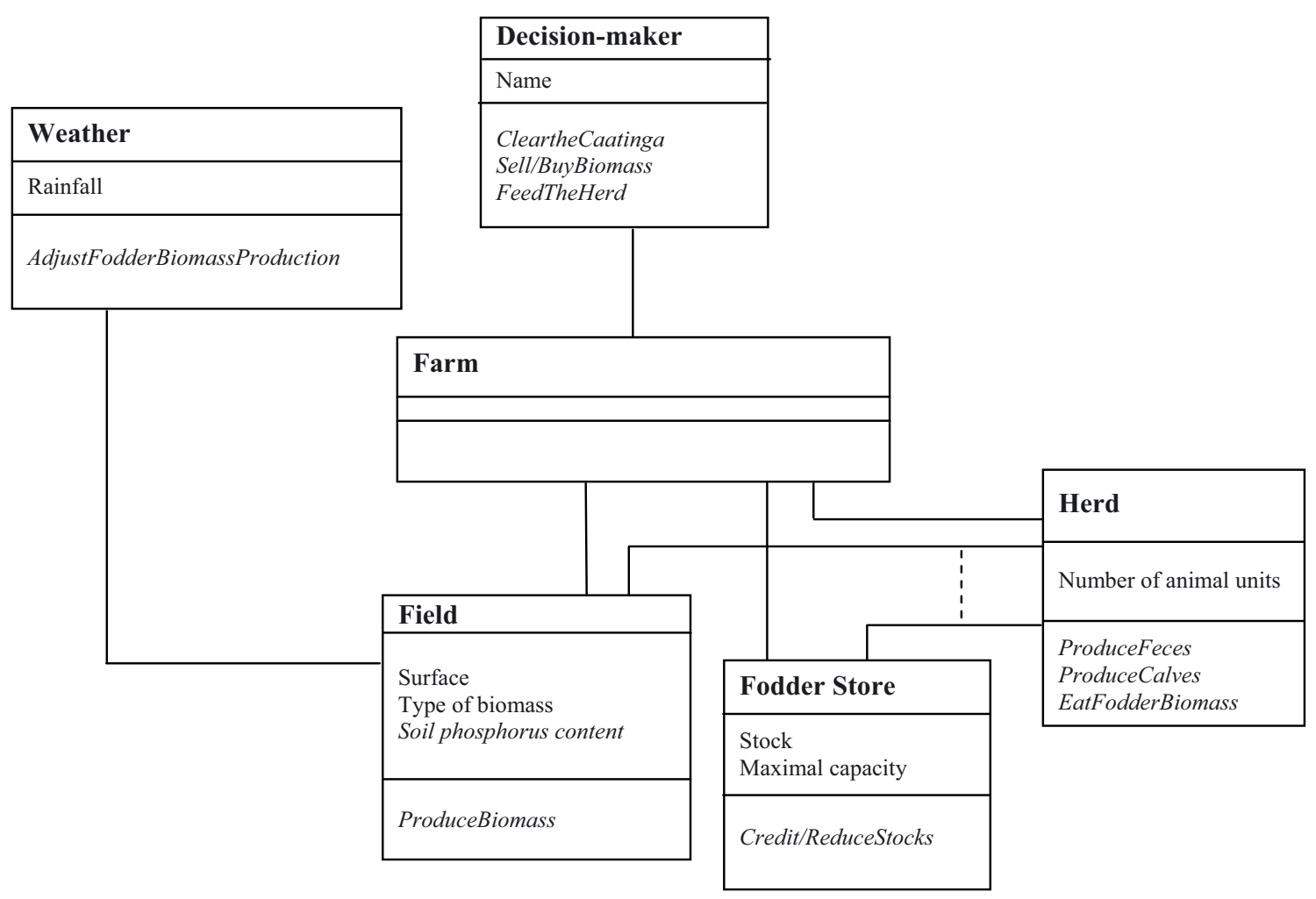

Figure 1. Class diagram presenting the structure of the model. Each box corresponds to a specific class with its name in bold, the main attributes in the middle part of the box, and main functions in the lower part. The farm class is made up of a field class, a herd class and a fodder store class. The field class uses data from the weather class and is managed by the decision-maker class.

and suggestions for how to improve the model; and (2) a statement of how interested they were in using the model for their own farm, how they propose to use the model, and what score they gave to the session.

\section{RESULTS AND DISCUSSION}

\subsection{The model}

The purpose of the model is to analyze the long-term impact of different biomass management strategies on the clearing of Caatinga vegetation, buffel grass extension, soil phosphorus content, and the strength of the herd.

The model is composed of a decision sub-model, which is able to predict the decision a typical farmer would make while monitoring the given biomass flows, and a simplified biophysical sub-model, which is able to simulate biomass production. Each sub-model is made up of classes that describe the functionalities and attributes of the objects. The external environment is only described by the weather class because farmers typically give little consideration to market price fluctuations. Figure 1 shows the structure of the simulator with its classes, plus the attributes and functionalities of each class.

\subsubsection{Inputs}

The simulator uses two input text files, one containing the weather data and the other describing the characteristics of the farm. The "weather" data file is a list of seasonal rainfall data. This list determines the duration of the simulation.

The "farm" file contains the attributes of the "fodder store", "herd" and "field" classes. In this file, the user specifies the initial amount of fodder stocks in the store and its maximum stocking rate. The user also specifies an initial number of animal units and the kind of fields that make up the farm, with measurements of the surface area, initial amount of biomass and initial soil phosphorus content. Four production areas were considered in our model: sorghum, buffel grass, paddle cactus, and native vegetation of Caatinga.

\subsubsection{The decision sub-model}

The decision sub-model is described by the "decisionmaker" class, which controls biomass flows through three kinds of processes: (1) clearing of the native vegetation of Caatinga; (2) feeding of the herd; and (3) selling of the animals.

The native vegetation of Caatinga is usually cleared when the fodder balance is overdrawn in two consecutive years. A given area of Caatinga is then cleared and replaced by buffel grass. The cleared area corresponds to the maximum clearing 
capacity of the farmer in one year. In practice, the maximum clearing capacity varies from one farm to another depending on whether the farmer has access to external labor. The default value of the cleared area is 1.5 ha per year, which corresponds to the average size of a patch cleared only using family labor. This value can be modified by the user in our model. Clearing can lead to the complete disappearance of native Caatinga vegetation from a farm, and thus this practice is used solely to cope with bad climatic years.

We assumed that during the dry season, the animal feed is based on buffel grass. Stocks of sorghum are used to feed the herd when there is no more buffel grass. A surplus of sorghum can be kept for use in the following year. The areas of paddle cactus and native vegetation of Caatinga if present are to be used in the event of insufficient production of buffel grass or sorghum. The biomass that is available on the farm can be insufficient for animal requirements, which indicates a need to purchase fodder stocks or rent external grazing areas.

For selling the animals, we considered that the farmer sells $10 \%$ of productive females each year, in addition to all male calves. This $10 \%$ usually corresponds to the older or less productive females. Female calves are kept to ensure that the herd size can increase until the size of the herd reaches a maximum threshold, which depends on the available area of buffel grass. This rule reflects the logic of the farmers that is based on the increase in the herd. The threshold can also vary from one farm to another depending on the production objective of the farmer. The default value is 1.2 animal units per ha of buffel grass; this value corresponds to the buffel grass potential stocking rate. This parameter is one of the most sensitive, since a difference of $10 \%$ corresponds to a change of $19 \%$ in the average number of animal units simulated.

Specific management strategies can be accounted for by modifying the number of areas, the animal carrying capacity or the decisional parameters.

\subsubsection{The biophysical sub-model}

Three classes of objects are considered in the biophysical sub-model: weather, herd and field.

\subsubsection{The weather class}

Rainfall is the main weather constraint. The weather class is described by two kinds of years: above-average-rainfall and below-average-rainfall, the average value being $563 \mathrm{~mm}$. In actual yearly rainfall data, $52 \%$ of the values are below this average value. For each kind of year, a specific coefficient determines biomass production.

\subsubsection{The herd class}

The herd class is described by the total number of animals and the number of cows; a cow corresponds to one animal unit of $250 \mathrm{~kg}$ live weight. The class has three principal functions: (1) to eat plant biomass, (2) to produce feces, and (3) to produce calves.
The daily consumption of dry matter ranges between $3 \%$ and 5\% of live weight (NRC, 2001). For an animal unit weighing $250 \mathrm{~kg}$, the default amount of dry matter that is consumed is around $10 \mathrm{~kg}$ of dry matter per animal unit per day.

The production of feces allows us to calculate the return of phosphorus (Eq. (1)) by the herd to the fields while grazing. This return is a function of the residence time (Eq. (2)) in the field. The minimal excretion of phosphorus by feces per ani$\mathrm{mal}$ and per day is around $5.72 \mathrm{mg}$ per $\mathrm{kg}$ of animal live weight (Silva Filho et al., 2000).

$$
\mathrm{RP}=\mathrm{DEP} \times \mathrm{SH} \times \mathrm{RTHF} / \mathrm{SA}
$$

where:

$$
\begin{aligned}
& \mathrm{RP}=\text { return of phosphorus }(\mathrm{kg} / \mathrm{ha}) \\
& \mathrm{DEP}=\text { daily excretion of phosphorus in the feces } \\
& \quad \text { per animal unit }(\mathrm{kg} / \text { animal unit) } \\
& \mathrm{SH}=\text { size of the herd (number of animal units per herd) } \\
& \mathrm{RTHF}=\text { residence time of the herd in the field (day) } \\
& \mathrm{SA}=\text { surface area }(\mathrm{ha}) \\
& \mathrm{RTHF}=\mathrm{AB} /(\mathrm{AR} \times \mathrm{SH}) \\
& \mathrm{RTHF}=\text { residence time of the herd in the field (day) } \\
& \mathrm{AB}=\text { available biomass in the field }(\mathrm{kg}) \\
& \mathrm{AR}=\text { animal's daily requirement }(\mathrm{kg} / \mathrm{animal} \text { unit/day) } \\
& \mathrm{SH}=\text { size of the herd (number of animal units). }
\end{aligned}
$$

For the production of calves (Eq. (3)), we used a death rate of $12 \%$ in the first year of life, a litter size of $90 \%$, and a rate of parturition per year of $66 \%$ (Azevêdo et al., 2006). The production of calves is calculated as follows:

$$
\mathrm{PC}=\mathrm{NC} \times \mathrm{RPY} \times \mathrm{LS} \times(1-\mathrm{MRC})
$$

where:

$$
\begin{aligned}
& \mathrm{PC}=\text { production of calves (calves per year) } \\
& \mathrm{NC}=\text { number of cows (cows per year) } \\
& \mathrm{RPY}=\text { rate of parturition per year }(\%) \\
& \mathrm{LS}=\text { litter size }(\%) \\
& \mathrm{MRC}=\text { mortality rate of the calves in the first year } \\
& \quad \text { of life }(\%) .
\end{aligned}
$$

The number of animal units (Eqs. (4) and (5)) changes every year as a function of mortality and the rate of sale, which is governed by the decision-maker class. Female calves that are kept in the herd are included in the cow class two years later.

$$
\mathrm{NAU}=\mathrm{NC}_{\mathrm{CY}} \times(1-\mathrm{MRAU})+\mathrm{PC}-\mathrm{SAU}
$$

where:

$$
\begin{aligned}
& \mathrm{NC}_{\mathrm{CY}}=\text { number of cows in the current year } \\
& \mathrm{MRAU}=\text { mortality rate of animal units } \\
& \mathrm{PC}=\text { production of calves (calves/year) } \\
& \mathrm{SAU}=\text { sale of animal units } \\
& \mathrm{NC}_{\mathrm{CY}}=\mathrm{NC}_{\mathrm{LY}}-\mathrm{SFC}+\mathrm{YCIH}
\end{aligned}
$$


Table I. Farm attributes for the simulated strategies.

\begin{tabular}{lccc}
\hline & Strategy 1 & Strategy 2 & Strategy 3 \\
\hline Total area (ha) & 75 & 75 & 31 \\
Number of animal units per total ha & 0.33 & 0.47 & 1.16 \\
Number of animal units per ha of buffel grass & 1.66 & 1.06 & 1.16 \\
Area of paddle cactus $($ ha) & 2 & 0 & 0 \\
Area of sorghum (ha) & 1 & 1 & 0 \\
Area of caatinga (ha) & 57 & 41 & 0 \\
Area of buffel grass (ha) & 15 & 33 & 31 \\
Initial soil P content in buffel grass area (kg/ha) & 10 & 7 & 19 \\
\hline
\end{tabular}

Table II. Simulation results for the three strategies.

\begin{tabular}{lccc}
\hline & Strategy 1 & Strategy 2 & Strategy 3 \\
\hline Number of years with fodder deficit & 0 & 6 & 9 \\
Average fodder deficit (t) & 0 & 3.6 & 15 \\
Variation in the number of animal units at the end of the simulation & - & +12 & +6 \\
Average number of animal units sold each year & 10 & 17 & 15 \\
Variation in the Caatinga area at the end of the simulation $(\mathrm{ha})$ & - & -6 & - \\
Soil P content in the buffel grass area at the end of the simulation $(\mathrm{kg} / \mathrm{ha})$ & 0 & 0 & 0 \\
\hline
\end{tabular}

where:

$$
\begin{aligned}
& \mathrm{NC}_{\mathrm{CY}}=\text { number of cows in the current year } \\
& \mathrm{NC}_{\mathrm{LY}}=\text { number of cows in the last year } \\
& \mathrm{YCIH}=\text { young cows }(2 \text { years old }) \text { included in herd. }
\end{aligned}
$$

\subsubsection{The field class}

The field class is described by three attributes: (1) the nature of the area, e.g., sorghum, buffel grass, Caatinga native vegetation, or paddle cactus; (2) the surface; and (3) the soil phosphorus content.

The main function of the field class is to produce fodder biomass. Each kind of area is characterized by a specific production potential corresponding to the available biomass at grazing: $4 \mathrm{t} / \mathrm{ha}$ of dry matter for sorghum, $3 \mathrm{t} / \mathrm{ha}$ for buffel grass, $2 \mathrm{t} /$ ha for paddle cactus, and $0.3 \mathrm{t} / \mathrm{ha}$ for Caatinga native vegetation (Menezes and Sampaio, 2002; Salviano et al., 2004), which is determined by the type of year, e.g., aboveaverage or below-average rainfall. The biomass production is calculated as follows (Eq. (6)):

$$
\begin{aligned}
& \mathrm{CB}=\mathrm{SA} \times \mathrm{WC} \times \mathrm{PP} \\
& \mathrm{CB}=\text { crop biomass }(\mathrm{t}) \\
& \mathrm{SA}=\text { surface area }(\mathrm{ha}) \\
& \mathrm{WC}=\text { weather coefficient }(\%) \\
& \mathrm{PP}=\text { potential production }(\mathrm{t} / \mathrm{ha}) .
\end{aligned}
$$

The production of biomass results in the export of part of the soil phosphorus content. Phosphorus export corresponds to $0.15 \%$ of the production of buffel grass and paddle cactus and $0.25 \%$ of the production of sorghum (Menezes and Sampaio, 2002; Valadares Filho et al., 2006). For Caatinga, the exports are considered negligible (Sampaio et al., 1994).

\subsection{Simulating strategies for biomass management}

\subsubsection{The simulations}

The simulations were made using data on three farming systems that are representative of the three main strategies of biomass management (Tab. I). The simulations were run using the same weather sequence over a 15 -year period.

With Strategy 1, there was no fodder deficit during the 15 -year period of the simulation. With Strategies 2 and 3, there were, respectively, 6 and 9 years of deficit, which corresponds to an average of 3.6 and 15 tons of dry matter (Tab. II).

An average of 10 animal units was sold each year with Strategy 1, 17 animal units with Strategy 2, and 15 animal units with Strategy 3.

With Strategy 1, there was no increase in the size of the herd at the end of simulation, whereas with Strategy 2, there was an increase of 12 animal units and with Strategy 3, an increase of 6 animal units. The larger increase in the number of animal units with Strategy 2 was linked to the decrease in the area of native Caatinga vegetation. Indeed, after 15 simulated years, the area of Caatinga decreased by 6 ha to enable an increase in the area of buffel grass. Strategy 3, which has no strategic Caatinga area, was not able to increase the buffel area, and consequently had a limited ability to increase animal carrying capacity. Strategy 1 did not result in any clearing of the Caatinga vegetation because the number of animal units was able to be supported by the supply of fodder. Figure 2 shows that Caatinga areas were used most in years that led to fodder deficits with Strategies 2 and 3, particularly with Strategy 3 in years $2,4,5,6,8,9,10,14$ and 15 , which were below-averagerainfall years. These results show that higher production, in terms of number of animals produced and sold each year, depends on the clearing of Caatinga vegetation in Strategy 2 and 


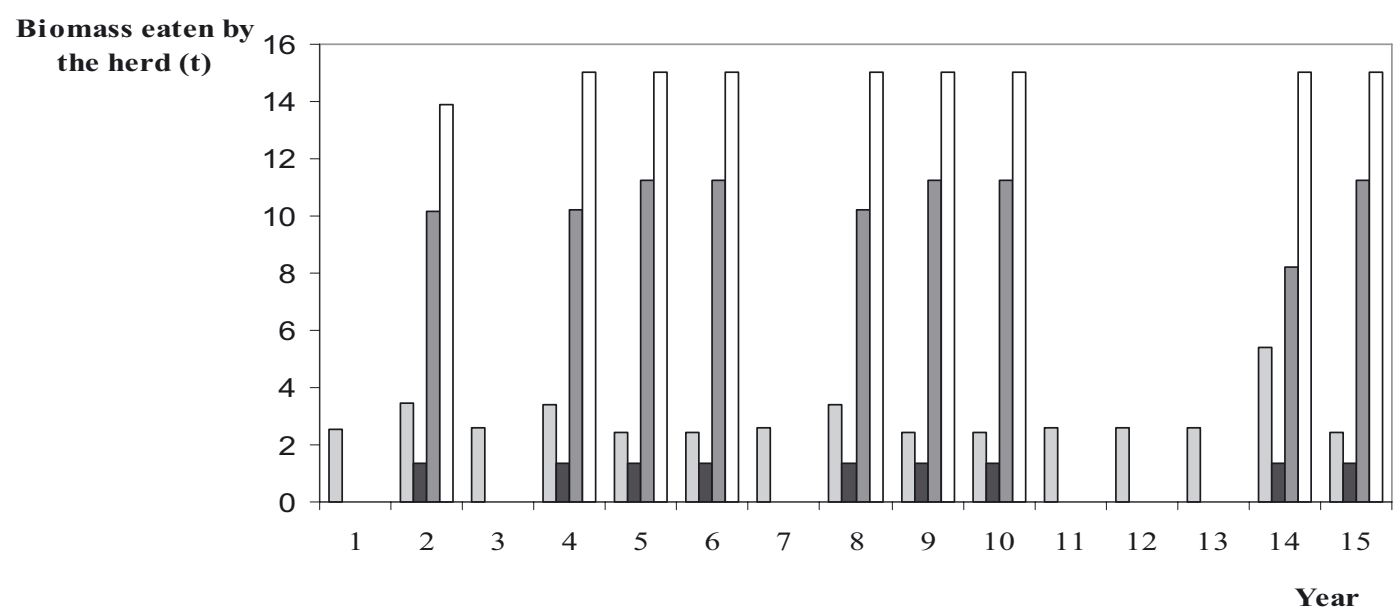

Figure 2. Simulated use of sorghum, paddle cactus and Caatinga biomasses by the herd in Strategy 1, and of external fodder with Strategy 3. In pale gray, sorghum biomass; in black, paddle cactus biomass; in dark gray, Caatinga biomass; and in white, external fodder needed to fulfill animal requirements. With Strategy 1, Caatinga vegetation was grazed in the years that led to fodder deficit with Strategy 3 . The amount of Caatinga vegetation grazed in these years varies according to available surplus of sorghum in the fodder store.

on external fodder in Strategy 3. Also, these data show that the Caatinga vegetation has a role in providing the flexibility to cope with climatic fluctuations. Lastly, these results show that environmental and economic issues are difficult to articulate.

Strategy 1 is the most self-reliant strategy, and consequently the least sensitive to external risks. The flexibility of a farming system is its capacity to deal with variations in the environment. Weiss (2001) identified operational flexibility as the ability to produce a large range of products. Here, the role of Caatinga in providing flexibility to the systems is to offer vegetation that is tolerant to drought and can be grazed during the dry season; it also allows for a diversification of the fodder areas in the farm.

Many authors have noted a poor coherence between environmental sustainability and economic profitability (Cuadra and Bjorklund, 2007; Hueting and Reijnders, 2004). Here, the strategy that most preserves the vegetation of Caatinga was found to be the least productive. Indeed, for several decades, research has promoted the clearing of native Caatinga vegetation for the cultivation of more productive fodder crops. We can identify a link between these two objectives by pointing to existing studies on the selection of Caatinga native species that can be used for fodder, wood or fruit production or on the sprouting of woody species after different periods of cutting (Figueirôa et al., 2006).

All three strategies lead to a decrease in soil phosphorus content (Tab. II). Only partial balances were simulated to model only those processes that can be easily quantified by farmers. Erosion was not taken into account. As cultivated crops are generally located in the lower parts of the toposequence, whereas buffel grass areas and Caatinga are located in the erosion-sensitive upper parts of the toposequence, such erosion processes are likely to be a source of nutrient import for cultivated crops and a source of export for areas of buffel grass and Caatinga native vegetation.
The negative phosphorus balances that were simulated with all three strategies indicate that at the farm level, the direction of the nutrient flow is from the cultivated areas to the other farm components, rather than vice versa, as noted by Defoer et al. (1998) in semi-arid conditions in Africa.

\subsubsection{The learning process with the 21 farmers}

Caatinga is mainly a buffer in all these systems, and there is no specific management of Caatinga areas. Farmers were not informed of current alternative techniques for managing Caatinga vegetation, such as enrichment with native species or cutting modes. We also discussed the possibility of taking sheep breeding into account in the production parameters. Indeed, in this zone cattle is grown for the sake of prestige, but sheep breeding, with its high female litter size, is an alternative strategy.

Figure 3 shows that more than $90 \%$ of the farmers agreed with the rules simulated by the model, indicating that the theories and simplifications in the model are justified and conceptually validated. More than $80 \%$ of the farmers judged the outputs accurate, providing us with an operational validation of the model (Rykiel, 1996). Other methods of validation could have been tested. For example, we could have compared the outputs of the model with those of other models or with real data, which could have allowed us to evaluate whether or not the model was able to accurately simulate the changes in variables. With our method, however, we were also able to assess the extent to which the farmers understood our model and were interested in using it as a tool. The aim of this research was not to design a predictive or normative tool but to design a discussion support tool that was able to illustrate the trends and potential impacts of current management practices to farmers and teach farmers about the impact of their practices. In this case, experimentation is complementary to modeling and 

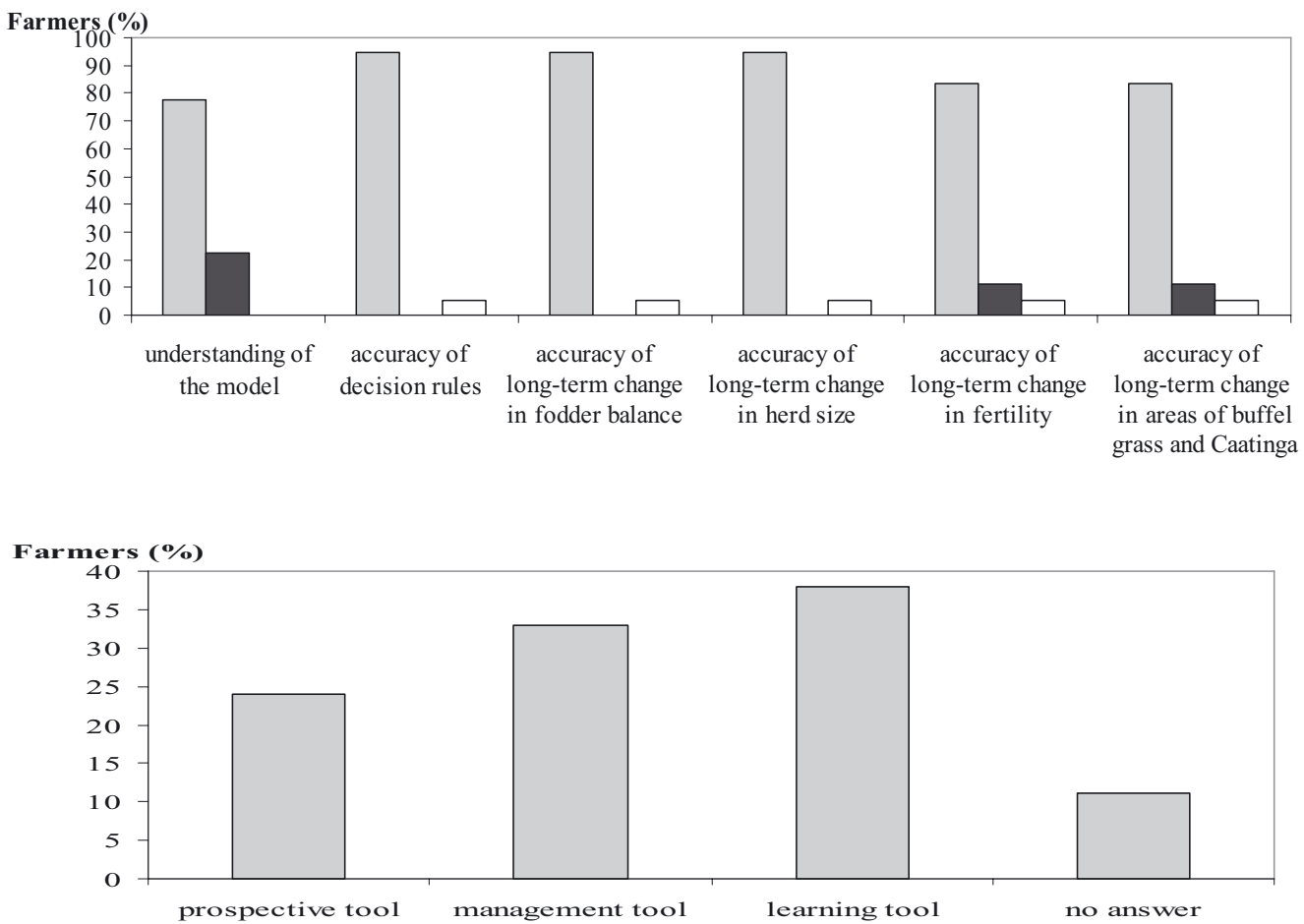

(b)

Figure 3. Farmer perception of the model (a) and its potential use (b). In figure (a), the number of farmers who responded "yes" is represented in pale gray; those who responded "no" are shown in black, and those who did not respond are shown in white. Figures (a) and (b) illustrate the validity and utility of the model.

allows the thresholds for technical propositions to be calculated more precisely.

Our method of validation is similar to that carried out for companion modeling approaches that link agent-based models and participatory research (Becu et al., 2008). In these cases, models are evaluated for the accuracy with which they represent the views of specific stakeholders.

The first step of the validation consisted of explaining the simplifications of the model. Rivington et al. (2007) reported that even when the uncertainty in the model estimates is not quantified, the process of engagement by the stakeholders, who communicate about both the insights and limitations of analyses, can be the best way of ensuring adequate debate. Nevertheless, even given the simplicity of the model, many of the farmers involved in this validation did not attend high school and perhaps had insufficient skills to really evaluate the simplifications of phosphorus fluxes.

Farmers proposed using this model not only as a learning tool but also as a management tool to analyze the fodder requirements and as a prospective tool. The questionnaires were anonymous, and thus we were not able to analyze how each farmer's evaluation correlated with his management strategies or the structural characteristics of his farm.

$57 \%$ of the farmers were frustrated they were not able to run the model themselves. It could have been possible to train these farmers to use computers, but in this kind of research, the model is not the issue in itself but rather the discussions that emerge in response to the simulation process. In other words, the model is more of a tool that acts as an intermediary (Vinck, 1999) between farmers and researchers.

\section{CONCLUSION}

The farm-scale model built in this study simulates biomass flows for buffel grass, paddle cactus, sorghum and Caatinga areas. In the model, flows are managed by a virtual farmer making decisions on when to clear Caatinga vegetation, feeding, and the sale of animals. The model was processed in an annual time step. The model was used to compare the impact of different types of management strategies on farm resources. The simulations show that the strategy that best preserves Caatinga areas is also the strategy that is the least sensitive to bad years and results in the lowest increase in herd size. These results emphasize the role of Caatinga vegetation in improving the ability of the farming system to cope with ongoing risks and the difficulty of dealing with environmental and production issues. We validated this model with farmers. They expressed an interest in using the model as a learning tool, a management tool and a prospective tool. Modeling and simulating biomass flows is thus an efficient framework for farmers to learn about their management practices. Unlike existing sophisticated models that are intended to be predictive tools, this model acts as an intermediary between farmers and researchers to promote learning about the practices. The objectoriented structure of the model should allow complexity to be 
added as farmers gain an understanding of the interaction between biophysical and decisional processes and as the discussion improves mutual learning of farming systems.

\section{REFERENCES}

Andrieu N., Piraux M., Tonneau J.P. (2007) Design of sustainability indicators of the production systems in Brazilian semi-arid area by the analysis of biomass flows, Int. J. Sust. Dev. 10, 106-121.

Azevêdo D.M.M.R., Filho R.M., Lôbo R.N.B., Malhado C.H.M., Lôbo R.B., Moura A.A.A., Filho E.C.P. (2006) Desempenho reprodutivo de vacas Nelore no Norte e Nordeste do Brasil, Rev. Bras. Zootec. 35, 988-996.

Becu N., Neef A., Schreinemachers P., Sangkapitux C. (2008) Participatory computer simulation to support collective decisionmaking: Potential and limits of stakeholder involvement, Land Use Policy 25, 498-509.

Bockstaller C., Guichard L., Makowski D., Aveline A., Girardin P., Plantureux S. (2008) Agri-environmental indicators to assess cropping and farming systems, A review, Agron. Sustain. Dev. 28, $139-149$.

Briggs L., Twomlow S.J. (2002) Organic material flows within a smallholder highland farming system of South West Uganda, Agr. Ecosyst. Environ. 89, 191-212.

Coquillard P., Hill D.R.C. (1997) Modélisation et simulation d'écosystèmes, des modèles déterministes aux simulations à évènements discrets, Masson, Paris.

Cros M.J., Duru M., Peyre D. (2001) SEPATOU : un simulateur de conduites du pâturage, à l'épreuve des "menus" bretons, Fourrages 167, $365-383$.

Cuadra M., Bjorklund J. (2007) Assessment of economic and ecological carrying capacity of agricultural crops in Nicaragua, Ecol. Ind. 7, $133-149$.

De Jager A., Onduru D., van Wijk M.S., Vlaming J., Gachini G.N. (2001) Assessing sustainability of low-external-input farm management systems with the nutrient monitoring approach: a case study in Kenya, Agr. Syst. 69, 99-118.

Defoer T., Groote H.D., Hilhorst T., Kante S., Budelman A. (1998) Participatory action research and quantitative analysis for nutrient management in southern Mali: a fruitful marriage? Agr. Ecosyst. Environ. 71, 215-228.

Figueirôa J.M., Pareyn F.G.C., Araujo E.L., Silva C.E., Santos V.F., Cutler D.F., Baracat A., Gasson P. (2006) Effects of cutting regimes in the dry and wet season on survival and sprouting of woody species from the semi-arid caatinga of northeast Brazil, Forest Ecol. Manag. 229, 294-303.

Haberl H., Fischer-Kowalski M., Krausmann F., Weisz H., Winiwarter V. (2004) Progress towards sustainability? What the conceptual framework of material and energy flow accounting (MEFA) can offer, Land Use Policy 21, 199-213.

Haileslassie A., Priess J.A., Veldkamp E., Lesschen J.P. (2007) Nutrient flows and balances at the field and farm scale: Exploring effects of land-use strategies and access to resources, Agr. Syst. 94, 459-470.
Hakanson L. (1995) Optimal size of predictive models, Ecol. Model. 78, 195-204.

Hueting R., Reijnders L. (2004) Broad sustainability contra sustainability: the proper construction of sustainability indicators, Ecol. Econ. $50,249-260$.

Keating B.A., McCown R.L. (2001) Advances in farming systems analysis and intervention, Agr. Syst. 70, 555-579.

Menezes A.H.N., Araujo C.R., Oliveira L.M.S.R, Souza C.M., Oliveira L.S, Piraux M., Ramos P.R., Azevedo S.G. (2007) Formação de agentes de desenvolvimento sustentavel : dialogos entre o fazer técnico e o saber humanista, Editora e Grafica Franciscana, Juazeiro.

Menezes R.S.C., Sampaio E.V.S.B. (2002) Simulação dos fluxos e balanços de fosforo em uma unidade de produção agricola familiar no semi-arido paraibano, in: Silveira L.M., Peterson P., Sabourin E. (Eds.), Agricultura familiar e agroecologia no semi-árido: avanços a partir do Agreste da Paraíba, Rio de Janeiro, pp. 249-260.

NRC (2001) Nutrient requirements of dairy cattle, National Academic Press, Washington.

Rivington M., Matthews K.B., Bellocchi G., Buchan K., Stockle C.O., Donatelli M. (2007) An integrated assessment approach to conduct analyses of climate change impacts on whole-farm systems, Environ. Modell. Softw. 22, 202-210.

Rykiel E.J. (1996) Testing ecological models: the meaning of validation, Ecol. Model. 90, 229-244.

Sadok W., Angevin F., Bergez J.-É., Bockstaller C., Colomb B., Guichard L., Reau R., Doré T. (2008) Ex ante assessment of the sustainability of alternative cropping systems: implications for using multicriteria decision-aid methods. A review, Agron. Sustain. Dev. 28, $163-174$.

Salviano L.M.C., Oliveira M.C., Soares J.G.G., Albuquerque S.G. (2004) Desempenho de bovinos em pastagem de caatinga sob diferentes taxas de lotação, Embrapa Semi-Árido (CPATSA), Petrolina-PE.

Sampaio E.V.S.B., Salcedo I.H., Silva F.B.R. (1994) Fertilidade de solos do semi-arido do Nordeste, in : Reunião Brasileira de Fertilidade do Solo e Nutrição de Plantas : Fertilizantes: insumo básico para agricultura e combate a fome, Petrolina, EMBRAPA-CPATSA/SBCS, pp. 51-71.

Silva Filho J.C., Vitti D.M.S.S., Campos Neto O., Abdalla A.L. (2000) Exigência mínima de fósforo em novilhos da raça nelore, Pesqui. Agropecu. Bras. 35, 1861-1865.

Tamubula I., Sinden J.A. (2000) Sustainability and economic efficiency of agroforestry systems in Embu District, Kenya: An application of environmental modelling, Environ. Modell. Softw. 15, 13-21.

Tonneau J.P., Sabourin E., da Silveira L.M., Sidersky P. (2002) Modélisation des flux de biomasse : une approche de la fertilité dans l'agreste de la Paraiba (Brésil), Cah. Agric. 11, 127-136.

Valadares Filho S.D.C., Magalhães K.A., Rocha Junior V.R., Capelle E.R. (2006) Tabelas Brasileiras de Composição de Alimentos para Bovinos, Universidade Federal de Viçosa, Viçosa.

Vinck D. (1999) Les objets intermédiaires dans les réseaux de coopération scientifique, Revue Française de Sociologie 40, 385-414.

Weiss C.R. (2001) On flexibility, J. Econ. Behav. Organiz. 46, 347-356. 